\title{
PERAN SELF EFFICACY DALAM MENINGKATKAN KINERJA KOPERASI INDONESIA
}

\author{
Iriani Ismail \\ iriani.ismail@yahoo.com \\ Universitas Trunojoyo Madura
}

\begin{abstract}
Abstrak
Meningkatkan kinerja sumber daya manusia (karyawan) bukanlah suatu hal yang mudah karena kinerja mempunyai konsep yang beraneka ragam dan dapat dianalisa dari berbagai sudut pandang serta dipengaruhi oleh berbagai faktor. Tujuan penelitian ini adalah untuk mengetahui seberapa besar peran self efficacy yang terdiri dari; magnitude, generality, strength terhadap kinerja Perkoperasian di Indonesia di tengah sengitnya persaingan bisnis. Metode analisis yang digunakan dalam penelitian ini adalah metode deskriptif kuantitatif dengan teknik wawancara dan penyebaran kuesioner pada semua responden terpilih pengurus Koperasi. Analisis ini bertujuan untuk mendukung pengetahuan sebaran magnitude, generality, strength pada pengurus Koperasi-koperasi di Bangkalan yang menjadi obyek penelitian. Populasi yang berjumlah 75 Koperasi tersebar di seluruh Kabupaten Bangkalan yang terdiri dari 18 kecamatan. Hasil penelitian melalui teknik analisis Regresi Linear Berganda menemukan pengaruh terbesar self efficacy terhadap kinerja perkoperasian adalah magnitude, kemudian generality dan strength.
\end{abstract}

Kata kunci: self efficacy, magnitude, generality, strength, kinerja.

\section{THE ROLES OF SELF EFFICACY TO REACH COOPERATION PERFORMANCE IN INDONESIA}

\author{
Iriani Ismail \\ iriani.ismail@yahoo.com \\ Universitas Trunojoyo Madura
}

\begin{abstract}
Improving the performance of human resources (employees) is not an easy thing because the performance has so many concept and can be analyzed from different view points and are influenced by various factors.

The purpose of this study was to determine the self efficacy are summarized in the magnitude, generality, and strength. The analytical method used in this research is descriptive quantitative method with interview techniques and questionnaires on all respondents. This analysis aimed to determine the distribution of self efficacy at Cooperation management in Bangkalan that the object of this study. Population of 75 Coperations in all of the Bangkalan districts, are 18 districts. Those are the respondents in this study. The results find and identify just only the self efficacy as well as competencies that a capital o f Sustainable Cooperation living, start from magnitude, generality, at last strength.
\end{abstract}

Keywords: self efficacy, magnitude, generality, strength, performance. 


\section{Pendahuluan}

Keyakinan akan kemampuan diri sangat diperlukan agar dapat melaksanakan pekerjaan dengan baik. Banyak para pegawai yang kurang percaya diri/tidak yakin dengan kemampuannya, atau pasrah saja menerima nasib. Kondisi ini jika dibiarkan tentu saja akan berakibat buruk/tidak baik terhadap kepuasan kerja pegawai tersebut dan lebih lagi bagi pencapaian tujuan atau kinerja institusi/perusahaan dimana bekerja. Keyakinan diri (Self efficacy) dipandang dapat mengubah perilaku seseorang dalam mencapai tujuannya dan memperbaiki kinerjanya dalam perusahaan.

Setiap individu memiliki Self efficacy yang berbeda. Self efficacy mencerminkan persepsi ataupun keyakinan individu terhadap kemampuannya sekaligus sebagai komponen motivasional individu dalam menyelesaikan tugas tertentu, yang dikenal sebagai "ittention for effort allocation".

Self efficacy yang tinggi menjadikan seseorang selalu berpikir positif, mampu mengeksplorasi kemampuan diri semaksimal mungkin, tidak tergantung kepada orang lain, dan memiliki lingkungan pergaulan yang tidak terbatas. Pada dasarnya seseorang yang memiliki kepercayaan diri yang cukup besar akan merasa lebih nyaman dalam menghadapi segala masalah dan merasa cukup bekal dalam mengatasinya. Sedangkan seseorang pegawai yang memiliki self efficacy rendah mengindikasikan mudah menyerah saat menghadapi kesulitan-kesulitan yang dihadapi. Keadaan ini nantinya akan berpengaruh bagi pencapaian target perusahaan atau organisasi.

Koperasi merupakan salah satu kekuatan ekonomi yang tumbuh dan berkembang di kalangan masyarakat sebagai pendorong tumbuhnya perekonomian nasional sekaligus sebagai soko guru dalam perekonomian di Negara Indonesia. Pada masa pembangunan ini, perannya tidak hanya di bidang perekonomian saja, tetapi diharapkan bisa menjadi alat pemersatu bagi seluruh rakyat Indonesia. Namun ternyata sumbangan dan peranannya di dalam perekonomian nasional tersebut masih sangat terbatas. Berbagai permasalahan yag muncul dalam perkembangan perkoperasian di tanah air merujuk pada lemahnya sumber daya manusia yang ditandai oleh rendahnya kualitas sumber daya manusia. Kualitas sumber daya manusia dalam perkoperasian tidak sepenuhnya memperoleh perhatian serius sehingga dalam perjalannya muncul berbagai permasalahan. Kapasitas pelaku perkoperasian dalam menjalankan kehidupan koperasi dan dalam menghadapi tantangan ke depan memerlukan banyak hal dipertimbangkan dan penguatan termasuk nuansa keyakinan diri para pelaku tersebut.

Keyakinan diri/self efficacy merupakan salah satu faktor determinasi motivasional diri yang sangat mendukung peningkatan kinerja lembaga perkoperasian. Dengannya diharapkan mampu menghalau semua rintangan dan permasalahan yang selama ini selalu disampaikan ketika membicarakan perkembangan koperasi.

\section{Tujuan Penelitian}

1. Mengetahui besarnya pengaruh variabel self efficacy yang terdiri dari magnitude, generality, strength terhadap kinerja perkoperasian

2. Untuk mengetahui pengaruh variabel magnitude terhadap kinerja perkoperasian

3. Untuk mengetahui pengaruh variabel generality terhadap kinerja perkoperasian

4. Untuk mengetahui variabel pengaruh strengh terhadap kinerja perkoperasian 


\section{Kajian Pustaka}

Keyakinan diri atau Self efficacy adalah keyakinan seseorang terhadap kemampuannya mengorganisasikan dan melaksanakan tindakan-tindakan yang diperlukan untuk mencapai performansi tertentu (Schunk,1991). Secara harfiah, efikasi dapat diartikan sebagai kemujaraban diri (kamus Bahasa Indonesia). Bandura (1997) memaknakan self efficacy sebagai keyakinan akan kemampuan individu untuk dapat mengorganisasi dan melaksanakan serangkaian tindakan yang dianggap perlu untuk mencapai suatu hasil yang diinginkan. Self-efficacy adalah kemampuan generatif yang dimiliki individu meliputi kognitif, sosial, dan emosi. Kemampuan individu tersebut harus dilatih dan diatur secara efektif untuk mencapai tujuan individu.

Seringkali dalam kehidupan sehari-hari, ditemukan individu mengalami kegagalan meskipun mengetahui apa yang harus dilakukan dan memiliki kemampuan untuk melakukannya. Karenanya, self-efficacy sekaligus dapat dipandang sebagai konsep yang secara spesifik mengontrol keyakinan atas kemampuan yang dimiliki individu untuk meraih tujuan tertentu. Menurut Bandura \& Jourden (1991) mengatakan keraguan dapat mempengaruhi kemampuan yang dimiliki individu sehingga kemampuan tersebut tidak muncul, karena keraguan dapat melemahkan keyakinan untuk mencapai suatu tujuan tertentu. Selanjutnya Bandura juga mengatakan bahwa keyakinan merupakan salah satu regulasi diri yang menentukan seberapa bagus kemampuan yang dimiliki, dilatih secara terus menerus, dan berkontribusi dalam mencapai suatu keberhasilan. Selain itu, sebagai suatu konsep, selfefficacy pada umumnya dipahami sebagai tugas tertentu, dan self-efficacy juga mengacu pada keyakinan kemampuan individu mengatasi berbagai tuntutan dan situasi. Berdasarkan uraian tersebut, dapat disimpulkan bahwa self-efficacy merupakan keyakinan atas kemampuan yang dimiliki individu dalam mencapai tujuan dengan tingkat kesulitan tugas pada berbagai kondisi, mampu berfikir secara positif, meregulasi diri, dan keyakinan yang positif.

\section{Faktor-faktor yang mempengaruhi self-efficacy}

Menurut Bandura (1997) ada beberapa faktor penting yang mempengaruhi selfefficacy, yaitu:

\section{a. Pengalaman keberhasilan (Mastery Experience)}

Pengalaman keberhasilan merupakan sumber yang sangat berpengaruh dalam selfefficacy. Pengalaman keberhasilan yang diperoleh individu meningkatkan self-efficacy tersebut dan sebaliknya, kegagalan menurunkan self-efficacy. Keberhasilan menghasilkan kekuatan dan kepercayaan diri. Pengalaman keberhasilan individu lain tidak dapat mempengaruhi self-efficacy, tetapi apabila pengalaman keberhasilan itu dari dirinya maka akan mempengaruhi peningkatan self-efficacy.

Bandura juga mengatakan bahwa pengalaman keberhasilan menghasilkan kekuatan yang relatif untuk memperkuat keyakinan diri dibandingkan dengan model lain seperti strategi pemodelan, simulasi kognitif, pertunjukan yang sukses, instruksi tutorial. Faktor yang paling penting dalam pengembangan efikasi diri sepertinya adalah pengalaman masa lalu. Jika selama suatu periode waktu berhasil dalam kinerja, maka mungkin akan lebih mengembangkan rasa percaya diri dan keyakinan yang meningkat dalam kemampuan untuk melaksanakan tugas secara berhasil. Penyataan tersebut didukung oleh pernyataan 
Bandura yang menyatakan bahwa pengalaman sebelumnya merupakan sumber yang paling potensial.

\section{b. Pengalaman orang lain (Vicarious Experience or Modeling)}

Individu tidak dapat hanya mengandalkan pengalaman keberhasilan sebagai sumber informasi tentang kemampuan mereka. Penilaian efikasi merupakan bagian yang dipengaruhi oleh pengalaman orang lain sebagai contoh untuk mencapai keberhasilan. Modelling merupakan cara lain yang efektif untuk menunjukkan kemampuan efikasi individu. Kemampuan individu dinilai dari aktifitas yang dihasilkan dengan indikator memuaskan. Pada saat kepuasan itu harus diukur terutama dalam kaitannya dengan kinerja, maka perbandingan sosial berperan penting sebagai faktor utama dalam penilaian kemampuan diri.

Weinberg dalam Bandura (1997) mengatakan bahwa bersaing dapat menimbulkan keyakinan yang kuat untuk berhasil, sedangkan jika ada salah satu yang berhasil maka hal ini dapat menurunkan keyakinan individu lainya.

\section{c. Persuasi verbal (Verbal Persuasion)}

Menurut Bandura (1997) persuasi verbal berfungsi sebagai sarana untuk memperkuat keyakinan atas kemampuan yang dimiliki individu dalam mencapai tujuan. Individu dengan keyakinan secara verbal bahwa mereka memiliki kemampuan untuk menguasai tugas-tugas yang diberikan cenderung berusaha secara maksimal dan mempertahankannya. Keyakinan yang berkenaan dengan efikasi diri adalah sesuatu yang dipelajari (Ivancevich, dkk, 2007). Karenanya, keberhasilan persuasif secara verbal akan dapat memberikan dampak positif pada individu yaitu meningkatkan rasa percaya mereka dalam menghasilkan prestasi.

\section{d. Keadaan Fisiologis dan Afektif ( Physiological and Affective State)}

Informasi kemampuan individu sebagian besar didapatkan dari somatik yang diteruskan ke ranah fisiologis dan afektif. Indikator somatik individu sangat relevan dalam kesehatan fisik, fungsi kesehatan, dan coping dengan stres. Treatment yang menghilangkan reaksi emosional melalui pengalaman keberhasilan dapat meningkatkan keyakinan keberhasilan dengan memperbaiki perilaku yang sesuai pada kinerja.

Stres dapat mengurangi self-efficacy pada diri individu. Apabila tingkat stres individu rendah maka self-efficacy akan tinggi, sebaliknya apabila stres tinggi maka self-efficacy pada individu rendah. Ada empat hal dalam meningkatkan keyakinan efikasi yaitu dengan meningkatkan status fisik, mengurangi tingkat stres, kecenderungan emosi negatif, dan memperhatikan kesehatan tubuh.

Self efficacy yang tinggi ditunjukkan dengan perilaku sebagai berikut :

1. Be active - select best opportunity

2. Manage the situation - avoid or neutralize obstacles

3. Set goal - establish standarts

4. Plan, prepare, practice

5. Try hard, preserve

6. Creatively solve problems

7. Learn from setbacks 
8. Visualize success

9. Limit stress

Sejauh mana orang meningkatkan self efficacy melalui keberhasilan performansi, akan tergantung seberapa besar usaha yang dikeluarkan. Keberhasilan yang diperoleh melalui usaha yang besar memberikan efficacy yang lebih kecil dari pada keberhasilan yang diperoleh dengan usaha yang sedikit. Hal ini disebabkan karena performansi yang mudah dicapai memberikan kesan tingkat kemampuan diri yang lebih tinggi dari pada prestasi yang diperoleh melalui kerja yang lambat dan berat.

\section{Dimensi Self-Efficacy}

Self-efficacy memiliki beberapa dimensi yang mempunyai implikasi penting pada kinerja, artinya self-efficacy bersifat spesifik dalam tugas dan situasi yang dihadapi. Menurut Bandura (1997), dimensi sel-efficacy ada tiga yaitu Magnitude atau level, Generality, Strenght.

\section{a. Magnitude atau Level}

Magnitude atau level adalah persepsi individu mengenai kemampuannya yang menghasilkan tingkah laku yang akan diukur melalui tingkat tugas yang menunjukkan variasi kesulitan tugas. Tingkat kesulitan tugas tersebut mengindikasikan dimensi kecerdikan/kecerdasan, tenaga, akurasi, produktivitas, atau regulasi diri yang diperlukan untuk menyebutkan beberapa dimensi perilaku kinerja. Individu memiliki self efficacy yang tinggi pada tugas yang mudah dan sederhana, atau juga pada tugas-tugas yang rumit dan membutuhkan kompetensi yang tinggi. Individu yang memiliki self efficacy yang tinggi cenderung memilih tugas yang tingkat kesukarannya sesuai dengan kemampuannya.

Individu yang memilki tingkat yang tinggi memiliki keyakinan bahwa ia mampu mengerjakan tugas-tugas yang sukar juga memiliki self-efficacy yang tinggi sedangkan individu dengan tingkat yang rendah memiliki keyakinan bahwa dirinya hanya mampu mengerjakan tugas-tugas yang mudah serta memiliki self-efficacy yang rendah.

\section{b. Generality}

Self-efficacy juga berbeda pada generalisasi artinya individu menilai keyakinan mereka berfungsi di berbagai kegiatan tertentu. Generalisasi memiliki perbedaan dimensi yang bervariasi yaitu:

1) Derajat kesamaan aktivitas.

2) Modal kemampuan ditunjukan (tingkah laku, kognitif, afektif).

3) Menggambarkan secara nyata mengenai situasi.

4) Karakteristik perilaku individu yang ditujukan.

Penilaian ini terkait pada aktivitas dan konteks situasi yang mengungkapkan pola dan tingkatan umum dari keyakinan orang terhadap keberhasilan mereka.

Dimensi ini berkaitan dengan penguasaan individu terhadap bidang atau tugas pekerjaan. Individu dapat menyatakan dirinya memiliki self efficacy pada aktivitas yang luas, atau terbatas pada fungsi domain tertentu saja. Individu dengan self efficacy yang tinggi akan mampu menguasai beberapa bidang sekaligus untuk menyelesaikan suatu tugas. Individu 
yang memiliki self efficacy yang rendah hanya menguasai sedikit bidang yang diperlukan dalam menyelesaikan suatu tugas.

\section{c. Strength}

Keyakinan diri yang lemah disebabkan tidak didukung oleh pengalaman, sedangkan orang-orang yang memiliki keyakinan yang kuat, mereka akan bertahan dengan usaha mereka meskipun ada banyak kesulitan atau hambatan. Individu tersebut tidak akan kalah oleh kesulitan, karena kekuatan pada self-efficacy tidak selalu berhubungan terhadap pilihan tingkah laku.

Dimensi yang ketiga ini lebih menekankan pada tingkat kekuatan atau kemantapan individu terhadap keyakinannya. Sel efficacy menunjukkan bahwa tindakan yang dilakukan individu akan memberikan hasil yang sesuai dengan yang diharapkan. Self efficacy menjadi dasar melakukan usaha yang keras, bahkan ketika menemui hambatan sekalipun.

Individu dengan tingkat kekuatan tinggi akan memiliki keyakinan yang kuat akan kompetensi diri sehingga tidak mudah menyerah atau frustasi dalam menghadapi rintangan dan memiliki kecenderungan untuk berhasil lebih besar dari pada individu dengan kekuatan yang rendah.

Alwisol (2004) mengatakan bahwa efikasi adalah persepsi mengenai seberapa bagus diri dapat berfungsi dalam situasi tertentu. Efikasi diri berhubungan dengan keyakinan bahwa diri memiliki kemampuan tindakan yang diharapkan. Efikasi adalah penilaian diri, apakah dapat melakukan tindakan, bisa atau tidak bisa mengerjakan sesuai dengan yang dipersyaratkan.

Kreitner dan Kinicki (2004) juga mendefinisikan bahwa self efficacy sebagai $a$ person's belief about his or her chances of successfully accomplishing a specific task. Self efficacy dapat dikatakan sebagai faktor personal yang membedakan setiap individu. Karenanya, perubahan self efficacy dapat menyebabkan perubahan perilaku terutama dalam penyelesaian tugas dan tujuan. Self efficacy mengarah pada keyakinan individu bahwa dirinya dapat melakukan tindakan yang dikehendaki oleh situasi tertentu dengan berhasil. Dikaakan pula bahwa self efficacy merupakan keyakinan seseorang tentang kemampuannya mengatasi berbagai situasi. Efficacy berarti keefektifan, memiliki kekuatan untuk memperoleh akibat yang diinginkan.

Penilaian kemampuan sangat penting bagi individu, individu yang menilai terlalu tinggi kemampuannya bila melakukan kegiatan yang dapat diraih akibatnya ia mengalami kesulitan untuk menurunkan kredibilitasnya dan menderita kegagalan. Sebaliknya individu yang menilai terlalu rendah kemampuannya akan membatasi dirinya dari pengalaman yang menguntungkan, untuk itu individu harus memperoleh pengetahuan diri berkenaan dengan kemampuan, kecakapan fisik, dan keterampilan untuk mengatasi situasi-situasi tertentu.

Definisi lebih luas dan lebih tepat untuk perilaku organisasi positif diberikan oleh Stajkovic dan Luthans dalam Luthans (2005) yang mengatakan bahwa efikasi diri mengacu pada keyakinan individu mengenai kemampuannya untuk memobilisasi motivasi, sumber daya kognitif, dan tindakan yang diperlukan agar berhasil melaksanakan tugas dalam konteks tertentu.

\section{Proses Self efficacy}

Bandura (1997) mengatakan bahwa self efficacy mengatur fungsi manusia melalui 4 proses utama, yaitu : 
a. Proses kognitif

Self efficacy mempengaruhi proses berpikir yang dapat meningkatkan atau mengurangi performansi dan bisa muncul dalam berbagai bentuk, antara lain :

1. Konstruksi Kognitif

Sebagian besar tindakan pada awalnya dibentuk dalam pikiran. Konstruksi kognitif tersebut kemudian hadir sebagai penuntun tindakan. Keyakinan orang akan self efficacy, akan mempengaruhi bagaimana mereka menafsirkan situasi dan tipe-tipe skenario pengantisipasi dan memvisualisasikan masa depan yang mereka gagas. Orang dengan self efficacy yang tinggi akan memandang situasi yang dihadapi sebagai sesuatu yang menghadirkan kesempatan-kesempatan yang dapat dicapai. Mereka memvisualisasikan skenario kesuksesan yang dapat memberi arahan positif bagi kinerja mereka. Orang yang menganggap dirinya tidak mampu akan menafsirkan situasi yang tidak pasti sebagai sesuatu yang beresiko dan mereka akan cenderung memvisualisasikan kegagalan. Memvisualisasikan kesuksesan akan meningkatkan kinerja. Sementara membayangkan kegagalan akan menurunkan kinerja.

2. Inferential thinking

Fungsi utama berpikir adalah orang mampu untuk memprediksi hasil dari berbagai tindakan yang berbeda dan untuk menciptakan kontrol terhadap hal-hal yang mempengaruhi kehidupannya. Keterampilan-keterampilan dalam problem solving memerlukan pemrosesan kognitif dari berbagai informasi yang kompleks, ambigu dan tidak pasti, secara efektif. Fakta bahwa faktor-faktor prediktif yang sama mungkin memiliki prediktor yang berbeda menciptakan suatu ketidakpastian. Self efficacy yang tinggi diperlukan dalam menghadapi berbagai ketidakpastian.

\section{b. Proses Motivasional}

Kemampuan untuk memotivasi diri dan melakukan tindakan yang memiliki tujuan berdasarkan pada aktivitas kognitif. Orang memotivasi dirinya dan membimbing tindakannya melalui pemikirannya. Mereka membentuk keyakinan bahwa diri mereka bisa dan mengantisipasi berbagai kemungkinan outcome positif dan negatif, dan mereka menetapkan tujuan dan merencanakan tindakan yang dibuat untuk merealisasikan nilainilai yang ingin diraih di masa depan dan menolak hal-hal yang tidak diinginkan.

c. Proses Afektif

Keyakinan seseorang mengenai kemampuannya dipengaruhi seberapa banyak tekanan yang dialami ketika menghadapi situasi-situasi yang mengancam. Reaksi-reaksi emosional tersebut dapat mempengaruhi tindakan baik langsung maupun tidak langsung melalui pengubahan jalan pikiran. Individu yang memiliki self efficacy rendah cenderung mempercayai bahwa sesuatu itu lebih berat dari pada kenyataanya. Hal ini menimbulkan perasaan stress dan pandangan yang sempit terhadap bagaimana pemecahan terbaik dari masalah. Sebaliknya, individu dengan self efficacy tinggi memusatkan perhatian dan usaha mereka kepada kebutuhan situasi, serta meningkatkan usaha ketika dihadapkan pada rintangan. Orang yang percaya bahwa dirinya dapat mengatasi situasi yang mengancam, menunjukkan kemampuan. Oleh karena itu tidak merasa cemas atau terganggu oleh ancaman-ancaman yang dihadapinya. Sedangkan orang yang mengancam akan mengalami kecemasan yang tinggi.

\section{d. Proses Seleksi}

Dengan menyeleksi lingkungan, orang mempunyai kekuasaan akan menjadi apa. Pilihan-pilihannya dipengaruhi oleh keyakinan akan kemampuan personalnya. Orang akan menolak aktivitas-aktivitas dan lingkungan-lingkungan yang mereka yakini 
melebihi kemampuan mereka, tetapi siap untuk melakukan aktivitas dan memilih lingkungan sosial yang mereka nilai dapat mereka atasi. Semakin tinggi penerimaan self efficacy, semakin menantang aktivitas yang mereka pilih.

Self efficacy akan mempengaruhi tindakan yang dipilih oleh individu, seberapa besar usaha yang dilakukan, seberapa lama kegigihannya dalam menghadapi rintanganrintangan dan kegagalan, seberapa besar depresi dan stress yang dialami dalam proses strategi penanggulangan masalah (coping) dengan tuntutan lingkungan, serta tingkat prestasi yang dicapai. Sejumlah penelitian menemukan bahwa self efficacy merupakan variabel yang dapat mempengaruhi kinerja secara langsung dan memiliki hubungan yang kuat (Arsanti, 2009).

Beberapa penelitian yang dilakukan secara berbeda baik secara strategi ataupun metodologi, menunjukkan bahwa self efficacy dapat meningkatkan kinerja (Bandura \& Locke. 2003). Selanjutnya dikatakan bahwa hasil meta analisis yang dilakukan terhadap hubungan kausal antara self-efficacy, penetapan tujuan, dan kinerja, menunjukkan bahwa self efficacy berkontribusi secara signifikan terhadap motivasi dan kinerja. Efficacy tidak hanya dapat memprediksi fungsi dalam keperilakuan diantara individu pada tingkat efficacy yang berbedabeda, tetapi juga perubahan fungsi di dalam diri individu dari waktu ke waktu. Wigfield dan Eccles (1990) menemukan bahwa efficacy mempunyai pengaruh yang independent terhadap kinerja. Stajkovic \& Luthans (1998) juga mengatakan terdapat hubungan yang signifikan antara self-efficacy dan kinerja.

Penelitian yang dilakukan Arsanti (2009) menemukan bahwa self efficacy berhubungan positif secara signifikan terhadap kinerja. Karenanya, self efficacy yang tinggi akan meningkatkan kinerja individu.

Hasil atau temuan yang sama juga terdapat dalam penelitian yang dilakukan oleh Warsito (2004) yang menunjukkan bahwa terdapat hubungan kausal positif signifikan antara self efficacy dengan prestasi akademik $(\mathrm{r}=0,472)$. Hasil selanjutnya juga menemukan bahwa self efficacy berhubungan kausal baik secara langsung $(\mathrm{r} 5=0,222)$, maupun secara tak langsung $(\mathrm{r} 5=0,154)$, dengan prestasi akademik. Karena hubungan kausal langsung lebih kuat dari pada tak langsung, maka dapat disimpulkan bahwa prestasi akademik lebih dipengaruhi secara langsung oleh self efficacy.

\section{Cara Meningkatkan Self efficacy}

Terdapat beberapa saran yang diajukan oleh Baron dan Greenberg dalam Fakhrudin (2008) untuk meningkatkan self efficacy para karyawan. Saran tersebut adalah sebagai berikut:

- Give constructive-not destructive feedback.

Memberikan umpan balik yang bersifat membangun akan memfokuskan kepada cara untuk meningkatkan kinerja karyawannya bahwa mereka akan memperoleh kesuksesan yang diinginkan.

- Expose employees to models of good performance -and success.

Sumber efficacy yang utama berasal dari pengalaman, sehingga semakin banyak keahlian dan pengetahuan yang diperoleh dari pengalaman akan meningkatkan self efficacy.

- Seek continous improvement. Melaksanakan suatu program yang berkelanjutan untuk meningkatkan self efficacy. 


\title{
Pengertian Kinerja
}

\begin{abstract}
Hasibuan (2007:94) mendefinisikan prestasi kerja/kinerja sebagai suatu hasil kerja yang digunakan seseorang dalam melaksanakan tugas-tugas yang dibebankannya yang didasarkan atas kecakapan, pengalaman, dan kesungguhan serta waktu. Kinerja merupakan gabungan tiga faktor penting, yaitu kemampuan dan minat kerja karyawan. Kemampuan dan penerimaan atas penjelasan delegasi tugas dan tingkat motivasi seorang karyawan. Semakin tinggi ketiga faktor tersebut, semakin besar prestasi/kinerja karyawan. Kinerja adalah kuantitas atau kualitas sesuatu yang dihasilkan atau jasa yang diberikan oleh seseorang yang melakukan pekerjaan (Luthans, 2005). Kinerja merupakan prestasi kerja, yaitu perbandingan antara hasil kerja dengan standar yang ditetapkan (Dessler, 2000). Kinerja adalah hasil kerja baik secara kualitas maupun kuantitas yang dicapai oleh seseorang dalam melaksanakan tugas sesuai tanggung jawab yang diberikan (Mangkunegara, 2002). Kinerja adalah hasil atau tingkat keberhasilan seseorang secara keseluruhan selama periode tertentu dalam melaksanakan tugas dibandingkan dengan berbagai kemungkinan, seperti standar hasil kerja, target atau sasaran atau kriteria yang telah ditentukan terlebih dahulu telah disepakati bersama (Rivai dan Basri, 2005). Sedangkan Mathis dan Jackson (2006) menyatakan bahwa kinerja pada dasarnya adalah apa yang dilakukan atau tidak dilakukan pegawai. Manajemen kinerja adalah keseluruhan kegiatan yang dilakukan untuk meningkatkan kinerja perusahaan atau organisasi, termasuk kinerja masing-masing individu dan kelompok kerja di perusahaan tersebut. Kinerja merupakan hasil kerja dari tingkah laku (Amstrong, 1999:15). Pengertian kinerja ini mengaitkan antara hasil kerja dengan tingkah laku. Sebagai tingkah laku, kinerja merupakan aktivitas manusia yang diarahkan pada pelaksanaan tugas organisasi yang dibebankan kepadanya.
\end{abstract}

\section{Faktor-faktor yang Mempengaruhi Kinerja}

\section{a. Efektifitas dan efisiensi}

Bila suatu tujuan tertentu akhirnya bisa dicapai, kita boleh mengatakan bahwa kegiatan tersebut efektif tetapi apabila akibat-akibat yang tidak dicari kegiatan menilai yang penting dari hasil yang dicapai sehingga mengakibatkan kepuasan walaupun efektif dinamakan tidak efesien. Sebaliknya, bila akibat yang dicari-cari tidak penting atau remeh maka kegiatan tersebut efesien (Prawirosentono, 1999).

\section{b. Otoritas (wewenang)}

Otoritas menurut adalah sifat dari suatu komunikasi atau perintah dalam suatu organisasi formal yang dimiliki seorang anggota organisasi kepada anggota yang lain untuk melakukan suatu kegiatan kerja sesuai dengan kontribusinya (Prawirosentono, 1999). Perintah tersebut mengatakan apa yang boleh dilakukan dan yang tidak boleh dalam organisasi tersebut.

\section{c. Disiplin}

Disiplin adalah taat kepda hukum dan peraturan yang berlaku (Prawirosentono, 1999). Jadi, disiplin karyawan adalah kegiatan karyawan yang bersangkutan dalam menghormati perjanjian kerja dengan organisasi dimana dia bekerja.

\section{d. Inisiatif}

Inisiatif yaitu berkaitan dengan daya pikir dan kreatifitas dalam membentuk ide untuk merencanakan sesuatu yang berkaitan dengan tujuan organisasi. 


\section{Karakteristik Kinerja Karyawan}

Karakteristik orang yang mempunyai kinerja tinggi adalah sebagai berikut (Mangkunegara, 2002:68):

1. Memiliki tanggung jawab pribadi yang tinggi.

2. Berani mengambil dan menanggung resiko yang dihadapi.

3. Memiliki tujuan yang realistis.

4. Memiliki rencana kerja yang menyeluruh dan berjuang untuk merealisasi tujuannya.

5. Memanfaatkan umpan balik (feed back) yang konkrit dalam seluruh kegiatan kerja yang dilakukannya.

6. Mencari kesempatan untuk merealisasikan rencana yang telah diprogramkan.

\section{Indikator Kinerja Karyawan}

Indikator untuk mengukur kinerja karyawan secara individu ada enam indikator, yaitu (Robbins, 2006):

1. Kualitas. Kualitas kerja diukur dari persepsi karyawan terhadap kualitas pekerjaan yang dihasilkan serta kesempurnaan tugas terhadap keterampilan dan kemampuan karyawan.

2. Kuantitas. Merupakan jumlah yang dihasilkan dinyatakan dalam istilah seperti jumlah unit, jumlah siklus aktivitas yang diselesaikan.

3. Ketepatan waktu. Merupakan tingkat aktivitas diselesaikan pada awal waktu yang dinyatakan, dilihat dari sudut koordinasi dengan hasil output serta memaksimalkan waktu yang tersedia untuk aktivitas lain.

4. Efektivitas. Merupakan tingkat penggunaan sumber daya organisasi (tenaga, uang, teknologi, bahan baku) dimaksimalkan dengan maksud menaikkan hasil dari setiap unit dalam penggunaan sumber daya.

5. Kemandirian. Merupakan tingkat seorang karyawan yang nantinya akan dapat menjalankan fungsi kerjanya.

6. Komitmen kerja. Merupakan suatu tingkat dimana karyawan mempunyai komitmen kerja dengan instansi dan tanggung jawab karyawan terhadap kantor.

Dari berbagai pengertian di atas, self efficacy bersinggungan atau berkaitan dengan faktor kualitas dan kemandirian.

\section{Metodologi Penelitian}

Penelitian ini bertujuan untuk memperoleh gambaran mengenai seberapa besar pengaruh self efficacy terhadap kinerja perkoperasian di Bangkalan. Maka dari itu metode yang digunakan dalam penelitian ini adalah metode deskriptif - kuantitatif. Ini berarti, selain memberikan gambaran sepintas, penelitian ini juga mempergunakan alat analisis statistik

Dari konsep yang diajukan dalam skripsi ini terdiri dari dua variabel, yaitu terdiri atas variabel bebas (independent) dan variabel terikat/tidak bebas (dependent). Berdasarkan kajian logis, maka konsep yang diukur dalam penelitian ini ditetapkan sebagai berikut :

a) Variabel bebas (independent) adalah:

1. Magnitude (X1)

2. Generality (X2)

3. Strength (X3) 
b) Variabel tidak bebas/terikat (dependent) adalah kinerja (Y)

\section{Model Penelitian}

Gambar 1. Peran Self-efficacy Terhadap Kinerja

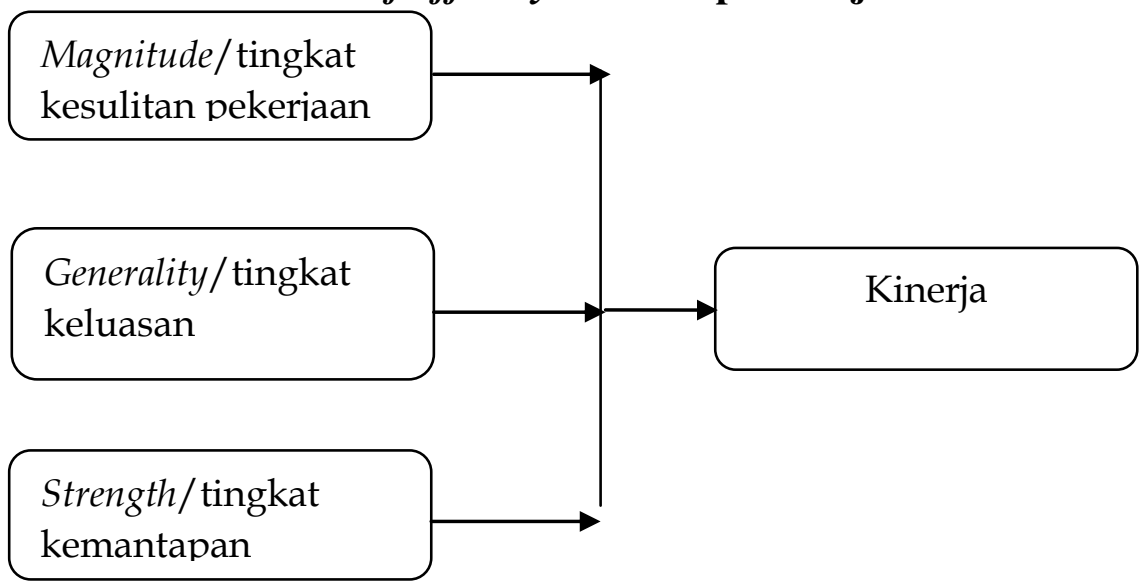

\section{Hasil Penelitian dan Pembahasan}

Penelitian ini melibatkan 75 koperasi aktif termasuk koperasi wanita (Kopwan) yang tersebar di 18 kecamatan, kabupaten Bangkalan, Madura. Koperasi aktif disini ditunjukkan oleh rutinitas melakukan laporan tahunan melalui RAT (Rapat Anggota Tahunan) selama 3 tahun berturut-turut. Data diperoleh dari Dinas Koperasi UMKM Bangkalan.

Teknik Analisis yang digunakan adalah analisis regresi linear berganda. Hasil ujinya menemukan signifikansi pengaruh ketiga variabel dalam self efficacy, yang terdiri dari variabel Magnitude, variabel Generality, dan variabel Strength terhadap variabel kinerja perkoperasian.

Penelitian ini diawali dengan pra survei di Dinas Koperasi UMKM Bangkalan, dilanjutkan kemudian ke lapangan disertai dengan pemberian kuesioner pada semua pelaku Koperasi tersebut. Banyaknya/jumlah koperasi yang terpilih sebagai responden di kecamatankecamatan di Bangkalan seperti berikut.

Tabel 1. Jumlah Responden

\begin{tabular}{|c|l|c|}
\hline No. & \multicolumn{1}{|c|}{$\begin{array}{c}\text { 18 Kecamatan yang tersebar di Kab. } \\
\text { Bangkalan }\end{array}$} & Jumlah Koperasi /responden \\
\hline 1 & Bangkalan & 5 \\
\hline 2 & Socah & 4 \\
\hline 3 & Kamal & 4 \\
\hline 4 & Burneh & 4 \\
\hline 5 & Kwanyar & 4 \\
\hline 6 & Tanah Merah & 5 \\
\hline 7 & Tragah & 4 \\
\hline 8 & Geger & 4 \\
\hline 9 & Klampis & 4 \\
\hline 10 & Arosbaya & 4 \\
\hline 11 & Tanjung Bumi & 5 \\
\hline 12 & Blega & 4 \\
\hline
\end{tabular}




\begin{tabular}{|c|l|c|}
\hline 13 & Konang & 4 \\
\hline 14 & Kokop & 4 \\
\hline 15 & Modung & 4 \\
\hline 16 & Galis & 4 \\
\hline 17 & Labang J u m l a h & 4 \\
\hline 18 & Sepulu & 4 \\
\hline \multicolumn{2}{|c|}{} \\
\hline
\end{tabular}

Dengan melakukan penyebaran kuesioner untuk mengukur persepsi responden digunakan skala Likert. Pertanyaan dalam kuesioner dibuat dengan menggunakan skala 1-5 untuk mewakili pendapat dari responden. Nilai untuk skala tersebut adalah:skor 5 (Sangat setuju), skor 4 (Setuju) skor 3 (Cukup Setuju) skor 2 (Tidak setuju) skor 1 (Sangat tidak setuju).

Hasil uji statistik seperti dalam tabel berikut menunjukkan bahwa semua variabel self efficacy: magnitude, generality, dan strength berpengaruh positif dan signifikan terhadap kinerja.

Pengaruh terbesar adalah variabel magnitude, artinya kinerja perkoperasian banyak dipengaruhi kekuatan keyakinan atas kemampuannya dalam melaksanakan tingkat kesulitan tugas perkoperasian. Selanjutnya variabel generality dan strength juga memberikan sumbangsih pengaruh bermakna bagi kinerja perkoperasian.

Tabel 2. Hasil Uji Regresi Linier Berganda

\begin{tabular}{|c|c|c|c|c|c|}
\hline \multirow{2}{*}{ Model } & \multicolumn{2}{|c|}{$\begin{array}{c}\text { Unstandardized } \\
\text { Coefficients }\end{array}$} & \multirow{2}{*}{$\begin{array}{c}\begin{array}{c}\text { Standardized } \\
\text { Coefficients }\end{array} \\
\text { Beta }\end{array}$} & \multirow{2}{*}{$\mathrm{t}$} & \multirow{2}{*}{ Sig } \\
\hline & B & $\begin{array}{l}\text { Std. } \\
\text { Error }\end{array}$ & & & \\
\hline (constant) & ,399 & 1,281 & &, 311 & ,757 \\
\hline $\mathrm{X} 1$ & ,367 &, 122 & ,333 & 2,993 & ,004 \\
\hline $\mathrm{X} 2$ & ,308 & ,096 & 290 & 3,199 & ,002 \\
\hline X3 & ,307 & 106 & ,310 & 2,908 & ,005 \\
\hline
\end{tabular}

Berdasarkan Tabel di atas maka persamaan regresi yang dihasilkan pada penelitian ini adalah:

$\mathrm{Y}=\alpha+\beta_{1} \mathrm{X}_{1}+\beta_{2} \mathrm{X}_{2}+\beta_{3} \mathrm{X}_{3}+\mathrm{e}$

$\mathrm{Y}=0,399+0,367 \mathrm{X}_{1}+0,308 \mathrm{X}_{2}+0,307 \mathrm{X}_{3}+\mathrm{e}$

Sebelum menganalisis bagaimana pengaruh self efficacy terhadap kinerja perkoperasian, terlebih dahulu dilakukan pengujian data kuesioner yang telah diperoleh. Pengujian meliputi uji validitas dan reliabilitas yang dilakukan dengan menggunakan SPSS (Statistical Product and Suuccess Solutions) 16 for Windows.

Setiap item kuesioner pada variabel dinyatakan valid apabila koefisien korelasinya lebih dari 0,3 (Sugiyono, 2005). Analisis hasil uji validitas dapat dilihat pada tabel berikut. 
Tabel 3. Hasil Uji Validitas Variabel Magnitude (X1)

\begin{tabular}{|c|c|c|c|}
\hline $\begin{array}{c}\text { Item } \\
\text { Pernyataan }\end{array}$ & Korelasi (r) & r Tabel & Keterangan \\
\hline X1.1 & 0,535 & 0,227 & Valid \\
\hline X1.2 & 0,376 & 0,227 & Valid \\
\hline X1.3 & 0,623 & 0,227 & Valid \\
\hline X1.4 & 0,383 & 0,227 & Valid \\
\hline
\end{tabular}

Variabel magnitude (X1) terdiri dari 4 item pernyataan. Korelasi setiap item pernyataan memiliki nilai $r$ hitung $>r$ tabel. Sehingga berdasarkan uji validitas menunjukkan bahwa pada semua item pernyataan pada variabel magnitude (X1) dinyatakan valid dan dapat dijadikan sebagai instrumen penelitan.

Tabel 4. Hasil Uji Validitas Variabel Generality(X2)

\begin{tabular}{|c|c|c|c|}
\hline $\begin{array}{c}\text { Item } \\
\text { Pernyataan }\end{array}$ & Korelasi (r) & r Tabel & Keterangan \\
\hline X2.1 & 0,446 & 0,227 & Valid \\
\hline X2.2 & 0,486 & 0,227 & Valid \\
\hline X2.3 & 0,697 & 0,227 & Valid \\
\hline X2.4 & 0,449 & 0,227 & Valid \\
\hline
\end{tabular}

Variabel Generality (X2) terdiri dari 4 item pernyataan. Korelasi setiap item pernyataan memiliki nilai $r$ hitung $>r$ tabel. Sehingga berdasarkan uji validitas menunjukkan bahwa pada semua item pernyataan pada variabel Generality (X2) dinyatakan valid dan dapat dijadikan sebagai instrumen penelitan.

Tabel 5. Hasil Uji Validitas Variabel Strength (X3)

\begin{tabular}{|c|c|c|c|}
\hline $\begin{array}{c}\text { Item } \\
\text { Pernyataan }\end{array}$ & Korelasi (r) & r Tabel & Keterangan \\
\hline X3.1 & 0,741 & 0,227 & Valid \\
\hline X3.2 & 0,498 & 0,227 & Valid \\
\hline X3.3 & 0,805 & 0,227 & Valid \\
\hline X3.4 & 0,467 & 0,227 & Valid \\
\hline
\end{tabular}

Variabel strength (X3) terdiri dari 4 item pernyataan. Korelasi setiap item pernyataan memiliki nilai $r$ hitung $>r$ tabel. Sehingga berdasarkan uji validitas menunjukkan bahwa pada semua item pernyataan pada variabel strength (X3) dinyatakan valid dan dapat dijadikan sebagai instrumen penelitan.

Tabel 6. Hasil Uji Validitas Variabel Kinerja Koperasi Madura (Y)

\begin{tabular}{|c|c|c|c|}
\hline $\begin{array}{c}\text { Item } \\
\text { Pernyataan }\end{array}$ & Korelasi (r) & r Tabel & Keterangan \\
\hline Y1 & 0,487 & 0,227 & Valid \\
\hline Y2 & 0,470 & 0,227 & Valid \\
\hline Y3 & 0,602 & 0,227 & Valid \\
\hline Y4 & 0,679 & 0,227 & Valid \\
\hline
\end{tabular}


Variabel kinerja koperasi madura (Y) terdiri dari 4 item pernyataan. Korelasi setiap item pernyataan memiliki nilai $r$ hitung $>r$ tabel. Sehingga berdasarkan uji validitas menunjukkan bahwa pada semua item pernyataan pada variabel kinerja koperasi madura (Y) dinyatakan valid dan dapat dijadikan sebagai instrumen penelitan.

\section{Hasil Uji Reliabilitas}

Reliabilitas adalah suatu pengujian yang akan menunjukkan konsistensi jawaban seseorang terhadap pernyataan yang ada dalam kuesioner tersebut dari waktu ke waktu di dalam mengukur gejala yang sama. Untuk menguji keandalan (reliabel) suatu pernyataan digunakan teknik analisis Cronbach's Alpha untuk tiap variabel penelitian melalui program SPSS 16. Uji reliabilitas digunakan metode Cronbach's Alpha, dimana suatu variabel dikatakan reliabel jika memberikan nilai Cronbach's Alpha > 0,60 (Ghozali, 2009). Hasil uji reliabilitas dari variabel-variabel yang diteliti dapat dilihat pada tabel berikut:

Tabel 6. Hasil Uji Reliabilitas

\begin{tabular}{|l|c|c|c|}
\hline \multicolumn{1}{|c|}{ Variabel } & $\begin{array}{c}\text { Cronbach's } \\
\text { Alpha }\end{array}$ & Kriteria & Keterangan \\
\hline Magnitude (X1) & 0,691 & 0,6 & Reliabel \\
\hline (X2) & 0,727 & 0,6 & Reliabel \\
\hline Strength $(\mathrm{X} 3)$ & 0,806 & 0,6 & Reliabel \\
\hline Kinerja Koperasi (Y) & 0,760 & 0,6 & Reliabel \\
\hline
\end{tabular}

Berdasarkan Tabel di atas diketahui bahwa nilai Cronbach's alpha dari variabel (X1), (X2), (X3), dan (Y) lebih dari 0,6 sehingga dapat disimpulkan reliabel, yang berarti bahwa kuesioner dapat digunakan dalam penelitian.

Berdasarkan hasil perhitungan yang ditunjukkan dalam tabel, maka seluruh item kuesioner pada variabel self efficacy $(\mathrm{X})$ dan variabel kinerja (Y) dinyatakan reliabel karena koefisien Alpha Cronbach-nya $(\alpha)$ lebih dari 0,6.

Daftar inventarisasi masalah Koperasi dan UMKM menunjukkan beberapa permasalahan baik pada Koperasi maupun UMKM. Permasalahan Koperasi dari tahun ke tahun terasa makin banyak khususnya pada sisi sumber daya manusia pelaku Koperasi. Temuan riset ini menunjukkan bahwa magnitude atau keyakinan atas kemampuan diri dalam melaksanakan tingkat kesulitan tugas dalam perkoperasian memberikan pengaruh dominan pada kinerja perkoperasian. Ini diindikasikan oleh kecerdasan/kecerdikan, tenaga/usaha, produktivitas, regulasi diri. Keadaan ini didukung oleh hasil inventarisasi permasalahan Koperasi oleh Kementerian Negara Koperasi \& UKM Republik Indonesia (2009) yang menemukan hal-hal antara lain sebagai berikut.

1. Kualitas sumber daya manusia di lingkungan Koperasi baik dari pemahaman perkoperasian maupun bisnis umumnya rendah,

2. Sebagian besar Koperasi belum melaksanakan RAT tepat waktu,

3. Kualitas dan partisipasi anggota Koperasi dari berbagai aspek rendah,

4. Rendahnya partisipasi anggota Koperasi disebabkan oleh motivasi keanggotaan yang tidak relevan dengan tujuan ideal keanggotaan Koperasi,

5. Motivasi keanggotaan Koperasi didorong oleh kepentingan jangka pendek,

6. Kewenangan pengurus mengangkat pengelola menciptakan tradisi kerja sambilan dalam kepengurusan Koperasi. 
Kenyataan di lapangan, sebagian besar sumber daya manusia institusi perkoperasian memang sangat rendah. Banyak masyarakat menganggap remeh kehidupan berkoperasi, sehingga menjalankan roda kehidupan koperasi dengan seadanya. Jangankan melakukan kreativitas/inovasi dalam pengelolaan perkoperasiaan, menjalankan dengan penuh tanggung jawab dan maksimal mengelolanya belum banyak ditemukan. Layak ditemukan dalam inventarisasi permasalahan koperasi Indonesia, karena di lapangan memang seperti itu adanya. Apalagi pendirian Koperasi yang diawali dengan pemberian pinjaman lunak, banyak dari koperasi-koperasi tersebut gulung tikar setelah memperolehnya. Keadaan seperti ini menunjukkan bahwa pendiriannya hanya sekedar untuk memperoleh pinjaman.

\section{Kesimpulan dan Saran}

Berdasarkan perhitungan secara kuantitatif atas penelitian yang dilakukan di beberapa Koperasi aktif dengan mengambil jumlah responden sebanyak 75 orang pengurus, maka dapat diuraikan beberapa kesimpulan sebagai berikut :

Hasil perhitungan secara statistik dengan alat bantu software SPSS 16 for windows menyatakan bahwa self efficacy memiliki pengaruh sebesar 67,7 \% terhadap kinerja Koperasi. Sehingga, bisa dikatakan jika self efficacy dikelola dengan baik, maka kinerja perkoperasian juga akan baik.

Self efficacy yang paling berpengaruh di lingkungan perkoperasian di Bangkalan yaitu magnitude, keyakinan diri bahwa mampu melaksanakan tingkat kesulitan tugas perkoperasian. Magnitude memberikan pengaruh 36,7\%, generality memberikan pengaruh $30,8 \%$, dan strength memberikan pengaruh $30,7 \%$.

Berdasarkan temuan tersebut, maka direkomendasi bahwa Koperasi adalah institusi yang sangat penting keberadaannya untuk mendukung pertumbuhan ekonomi, utamanya kesejahteraan para anggotanya. Karenanya perlu memperhatikan keberadaan sumber daya manusia yang tangguh dan handal dalam mengelola perkoperasian.

\section{Daftar Pustaka}

Alwisol. 2004. Psikologi Kepribadian. Malang: UMM Press

Amstrong, Mischael, 1999. Manajemen Sumber Daya Manusia. Terjemahan Sofyan dan Haryanto. Jakarta: PT. Elex Media Komputindo.

Arsanti, Tutuk Ari. 2009. Hubungan Antara Penetapan Tujuan dan Self Efficacy Terhadap Kinerja. Jurnal Bisnis dan Ekonomi. Jember Jurnal Bisnis dan Ekonomi. 16(2). 97110. ISSN : 1412-3126

Bandura, Albert \& Locke, Edwin. A. 2003. Negative Self-Efficacy and Goal Effects Revisited. Journal of Applied Psychology. Vol. 88, No. 1, 87-99.

Bandura, A \& Jourden FJ. 1991. Self Regulatory Mechanisms Governing Social Comparism Effects on Complex Decision Making. Journal of Personality and Social Psychology, 60, 941-951.

Bandura, A. 1997. Self Efficacy: The Excercise of Control. USA: WH Freeman and Company. 
Daftar Hasil Inventarisasi Masalah Koperasi dan UMKM, 2009. Kementrian Koperasi dan UKM RI. Jakarta

Dessler, Gary. 2000. Manajemen Sumber Daya Manusia, Edisi Terjemahan, Jakarta: PT. Prenhallindo

Fakhrudin, M. 2008. Program Percepatan Belajar sebagai Salah Satu Inovasi Labschool Dalam Memberikan Layanan Belajar Bagi Sisw Cerdas Istimewa. Jakarta.

Ghozali, Imam. 2009. Aplikasi Analisis Multivariate Dengan Program SPSS, Edisi Keempat, Semarang: Badan Penerbit Universitas Diponegoro

Ivancevich, J. M; Robert Konopaske, Michael T. Matteson. 2007. Perilaku dan Manajemen Organisasi. Jakarta: Erlangga

Kreitner, Robert, dan Kinicki, Angelo. 2004. Organizational Behavior. McGraw-Hill.

Luthans, F. 2005. Organizational Behavior. New York: McGraw-hill.

Mangkunegara, Anwar Prabu . 2002. Manajemen Sumber Daya Manusia. Bandung: Remaja Rosdakarya.

Meece JL, Wigfield A \& Eccles JS. 1990. Predictors of Matc Anxciety \& Its Influence on Young Adolescents ' Course Enrollment Intentions \& Performance in Mathematics. Journal of Educational Psychology, 82, 60-70.

Mathis, R.L. \& J.H. Jackson. 2006. Human Resource Management: Manajemen Sumber Daya Manusia. Terjemahan Dian Angelia. Jakarta: Salemba Empat.

Prawirosentono, Suryadi. 1999. Kebijakan Kinerja Karyawan. Yogyakarta: BPFE.

Rivai, Vethzal \& Basri. 2005. Peformance Appraisal: Sistem yang tepat untuk Menilai Kinerja Karyawan dan Meningkatkan Daya Saing Perusahan. Jakarta: PT. RajaGrafindo Persada.

Robbins, Stephen P., 2006. Perilaku Organisasi, PT Indeks, Kelompok Gramedia, Jakarta.

Schunk, DH. 1991. Self Efficacy\& Academic Motivation. Education Psychologist, 26, 207231.

Stajkovic, Alexander. D \& Luthans, Fred. 1997. Social Cognitive Theory and Self Efficacy: Going Beyond Traditional and Behavioral Approach. Field report. Organization Dynamics. Elsevier Science Publishing Company, Inc.

Sugiyono, 2005, Metode Penelitian Bisnis, Bandung : Alfabeta 